\title{
IMPLEMENTASI MODEL TEMATIK UNTUK MENGINTEGRASIKAN KEMAMPUAN SOSIAL DALAM PELAJARAN IPA SMA
}

\author{
Habibi \\ Prodi Pendidikan IPA, Universitas Wiraraja Sumenep
}

\begin{abstract}
ABSTRAK
Penelitian ini bertujuan untuk mendeskripsikan respon siswa, kepekaan sosial siswa dan faktor-faktor yang mempengaruhi pembelajaran biologi yang dikembangkan dengan model tematik. Jenis Penelitian ini adalah penelitian campuran, dimana perlakuan yang diberikan berupa pembelajaran Biologi menggunakan model tematik bersama dengan ilmu-ilmu sosial dianalisis secara deskriptif secara kualitatif (untuk mengetahui respon dan faktor-faktor yang mempengaruhinya) dan kuantitatif (perubahan moral reasoning sebagai landasan bagi nilai kepekaan sosial). Temuan yang dihasilkan dalam penelitian ini antara lain: respon siswa terbagi menjadi kelas produkstif, kelas produktif, dan kelas kontraproduktif, sedangkan nilai kepekaan sosial siswa dalam pembelajaran mengalami peningkatan. Faktor-faktor yang mempengaruhi proses pembelajaran berorientasi model tematik ini adalah tingkat pemahaman siswa terhadap materi sebelumnya, media pembelajaran dan jumlah jam pelajaran. Berdasarkan beberapa temuan yang didapatkan pada penelitian ini maka dapat diambil suatu kesimpulan bahwa pembelajaran biologi yang diintegrasikan dengan nilai sosial dapat diajarkan menggunakan model tematik.
\end{abstract}

Kata Kunci: Model Tematik, Kemampuan Sosial, Pelajaran Biologi

\section{PENDAhULUAN}

Pendidikan nasional bertujuan untuk meningkatkan kualitas manusia Indonesia, yaitu manusia yang beriman dan bertaqwa terhadap Tuhan Yang Maha Esa, Berbudi pekerti luhur, berkepribadian, mandiri, maju, tangguh, cerdas, kreatif, terampil, berdisiplin, beretos kerja, profesional, bertanggung jawab, produktif serta sehat jasmani dan rohani (GBHN, 1993). Sesuai dengan tujuan pendidikan nasional tersebut, Purwanto (2000) mendifinisikan tugas pendidikan adalah untuk membentuk manusia susila yang cakap, membentuk warga negara yang demokratis dan bertanggung jawab tentang kesejahteraan masyarakat dan tanah air. Kemampuan sosial siswa di masyarakat juga sangat ditentukan oleh bagaimana kondisi moralitas yang mereka miliki dan terapkan dalam kehidupan sehari-hari.

IPA, dan termasuk Biologi di dalamnya, adalah cabang sains yang membahas tentang alam secara fisik, sedangkan IPS adalah cabang sains yang membahas tentang manusia dan interaksiinteraksi sosialnya. Perpaduan diantara keduanya dengan menggunakan model pembelajaran terpadu tipe integrated dapat menjadi salah satu alternatif bagi pengembangan pendidikan IPA di sekolah yang mengintegrasikan nilai kepekaan sosial.

Pemaduan bidang pelajaran dapat dilakukan dengan metode tematik. Pembelajaran tematik adalah pembelajaran yang dirancang berdasarkan tema-tema tertentu. Dalam pembahasannya tema itu ditinjau dari berbagai mata pelajaran. Sebagai contoh, tema "Air" dapat ditinjau dari mata pelajaran fisika, biologi, kimia, dan matematika. Lebih luas lagi, tema itu dapat ditinjau dari bidang studi lain, seperti IPS, bahasa, dan seni. Pembelajaran tematik menyediakan keluasan dan kedalaman implementasi kurikulum, menawarkan kesempatan yang sangat banyak pada siswa untuk memunculkan dinamika dalam pendidikan. Unit yang tematik adalah epitome dari seluruh bahasa pembelajaran yang memfasilitasi siswa untuk secara produktif menjawab pertanyaan yang dimunculkan sendiri dan memuaskan rasa ingin tahu dengan penghayatan secara alamiah tentang dunia di sekitar mereka. 
Keuntungan pembelajaran tematik bagi guru antara lain adalah sebagai berikut:

1. Tersedia waktu lebih banyak untuk pembelajaran. Materi pelajaran tidak dibatasi oleh jam pelajaran, melainkan dapat dilanjutkan sepanjang hari, mencakup berbagai mata pelajaran.

2. Hubungan antar mata pelajaran dan topik dapat diajarkan secara logis dan alami.

3. Dapat ditunjukkan bahwa belajar merupakan kegiatan yang kontinyu, tidak terbatas pada buku paket, jam pelajaran, atau bahkan empat dinding kelas. Guru dapat membantu siswa memperluas kesempatan belajar ke berbgai aspek kehidupan.

4. Guru bebas membantu siswa melihat masalah, situasi, atau topik dari berbagai sudut pandang.

5. Pengembangan masyarakat belajar terfasilitasi. Penekanan pada kompetisi bisa dikurangi dan diganti dengan kerja sama dan kolaborasi.

Pembelajaran terpadu merupakan suatu pembelajaran yang memungkinkan siswa, baik secara individual maupun kelompok aktif mencari, menggali, dan menemukan konsep serta prinsip keilmuan secar holistik, bermakna dan otentik (Joni, 1996). Berbagai pelajaran dipadukan oleh suatu tema terkait niali sosial sehingga selain peningkatan nilai sosial, model ini akan menjadikan siswa dapat memahami beberapa pelajaran sekaligus dengan lebih baik. Dalam kerangka itulah penelitian ini dilakukan.

Kurikulum Tingkat satuan pendidikan (KTSP) yang baru berjalan selama dua tahun pada dasarnya merupakan salah satu perwujudan dari School Based Curriculum Development (Sistem Pengembangan Kurikulum Berbasis Sekolah). Dengan beberapa regulasi baru yang memberi peluang kepada sekolah dan para guru untuk menjadi pengembang kurikulum kiranya cukup memberi momen yang tepat bagi pelaksanaan program seperti Sains Integratif ini.

\section{METODE PENELITIAN}

Jenis Penelitian ini adalah penelitian campuran, dimana perlakuan yang diberikan berupa pembelajaran Biologi menggunakan model tematik bersama dengan ilmu-ilmu sosial dianalisis secara deskriptif secara kualitatif (untuk mengetahui respon dan faktor-faktor yang mempengaruhinya) dan kuantitatif (perubahan moral reasoning sebagai landasan bagi nilai kepekaan sosial). Subjek penelitian dalam implementasi model tematik dalam pembelajaran biologi ini adalah siswa SMA Tahdidz Prenduan Sumenp kelas XII. Jumlah kelas yang diteliti adalah sebanyak 7 kelas. Penelitian ini dilaksanakan di SMA Tahfidz Prenduan Sumenep pada bulan Agustus-September tahun 2010.

\section{HASIL DAN PEMBAHASAN \\ 3.1 Respon Siswa}

Respon siswa yang diamati dalam pelaksanaan program ini adalah berupa segala aktiviatas siswa selama pelajaran di kelas. Aktivitas tersebut dapat dipandang sebagai perwujudan dari tiga jenis respon siswa, yaitu:

1. Respon positif, yaitu segala aktivitas siswa yang mendukung terlaksananya proses belajar-mengajar yang kondusif sesuai dengan tujuan pembelajaran. Beberapa contoh respon positif adalah mendengarkan dengan antusias, bertanya, mengajukan pendapat, bahkan juga mengeluarkan guyonan ringan yang tidak mengacaukan konsentrasi kelas namun cukup membuat suasana menjadi tidak tegang.

2. Respon pasif, yaitu suatu aktivita khusus dimana siswa secara sekilas nampak mendengarkan namun jika diperhatikan lebih lanjut maka konsentrasinya peda pelajaran ternyata sangat kecil. Siswa dengan respon seperti ini hanya akan diam sepanjang 
pelajaran dan tanpa motivasi untuk benar-benar memahami dan berpatisipasi dalam mengikuti kegiatan kelas.

3. Respon negatif, yaitu segala aktiviatas siswa yang cenderung mengganggu jalannya proses belajar mengajar, menurunkan motivasi dan konsentrasi siswa-siswa lain. Beberapa contoh dari respon negatif ini adalah berbicara sendiri, mengeluarkan komentara yang tidak perlu dan juga gurauan yang berlebihan sehingga fokus kelas pada pelajaran menjadi terganggu dan juga tidur.

Berdasarkan pengamatan pelaksana program, respon siswa secara umum dalam melaksanakan proses belajarmengajar (dalam program sains integrasi ini) terbagi menjadi tiga kelompok besar yaitu:

1. Kelas produktif, yaitu kelas dimana sebagaian besar siswanya memiliki respon positif. Dalam kelas ini atmosfer yang dimunculkan selama proses belajar-mengajar benar-benar membantu guru (pelaksana program) untuk mewujudkan tujuan pembelajaran. Pemikiran kritis dan antusiasme siswa banyak memberikan penguatan informasi dan pemahaman antar sesame siswa dan bantuan kepada pelaksana program untuk mengembangkan metode pembelajaran yang lebih sesuai denagn tujuan dasarnya. Yang temasuk dalam kelas produktif ini adalah kelas IPA 1 dan kelas IPA 2,

2. Kelas biasa (menengah), yaitu kelas dengan sejumlah kecil siswa yang memiliki respon positf dan negatif, sedangkan jumlah yang terbesar adalah respon pasif. Walaupun secara umum pelajaran dapat berlangsung lancar dan tanpa hambatan, namun motivasi kelas untuk benar-benar berpartisipasi dalam pikiran dan pembicaran masih kecil. Kelas yang cenderung diam dan penurut adalah ciri utamanya. Sejumlah kecil siswa dengan respon positif kurang bisa memberi warna pada kelas karena secara psikologis diamnya sebagian besar teman-teman mereka pada akhirnya akan menurunkan motivasi. Para siswa dengan respon negatif juga segera dapat dihilangkan dengan penanganan tertentu dari guru. Yang termasuk jenis kelas menengah ini adalah kelas IPA 3, IPA 4, dan IPA 6.

3. kelas kontraproduktif, yaitu kelas dengan jumlah respon siswa adalah sebagaian besar respon negatif. Waktu yang tersedia pada kelas ini sebagian besar habis untuk menangani respon negatif yang muncul. Suasan ramai dan siswa susah diatur adalah ciri utama kelas ini. Walaupun begitu terdapat pelajaran yang dapat diperoleh pelaksana program sebagai bahan evaluasi. Yang termasuk kelas kontraproduktif ini adalah kelas IPA 5 dan IPS.

Adanya variasi respon yang ditunjukkan oleh siswa sehingga akhirnya membentuk tipe-tipe kelas yang berbeda tentunya disebabkan oleh faktor-faktor tertentu.

Motivasi merupakan suatu proses internal dalam diri seseorang untuk terus mempertahankan perilaku tertentu (Nur, 2003), oleh karena itu motivasi merupakan satu unsur yang paling penting dalam pembelajaran yang berhasil. Terdapat banyak teori mengenai motivasi yang dapat diaplikasikan dalam pembelajaran, dalam penelitian ini hasil respon siswa memberikan sebuah gambaran bahwa Model Pembelajaran Pemaknaan yang digunakan untuk mengembangkan perangkat pembelajaran Biologi pada KD melakukan percobaan mengenai pengaruh faktor luar terhadap pertumbuhan pada tumbuhan cukup dapat menumbuhkan motivasi belajar siswa.

Motivasi juga juga ditingkatkan dalam pembelajaran yang mengorientasikan tujuannya salah satunya pada sensitivitas moral, dalam penelitian ini melalui proses pemaknaan. Hal ini 
dikuatkan oleh penelitian yang dilakukan oleh Morton dan Testerman (2006) yang menyebutkan bahwa sensitivitas moral dapat memediasi perkembangan motivasi dan penalaran.

\subsection{Penalaran Moral (Moral Reasoning) Siswa}

Penalaran moral adalah suatu kemampuan logis yang dimiliki oleh manusia untuk memahami dan mengambil sikap terhadap sebuah permasalahan moral tertentu. Penalaran ini sangat diperlukan oleh setiap orang dalam menghadapi permasalahan yang tampaknya menjadi sangat rumit di zaman modern ini. Walaupun bukan penentu paling utama dalam pembentukan sikap moral, namun penalaran moral dapat menjadi penuntun bagi siswa agar selalu sadar akan sikap dan perbuatannya.

Karena bersifat rasional maka pengujian penalran moral ini memakai pendekatan kognitif, yaitu dengan menggunakan metode MJI yang pertama kali dipakai oleh Lawrence Kholberg pada tahun 1980-an. Pada metode ini siswa dihadapkan pada dilemma moral yang dirancang secara hopotetis. Jawaban siswa akan diberi nilai,untuk kemudian berdasarkan nilai tersebut mereka akan digolongkan pada tingkat penalaran moral tertentu.

Secara umum penalaran moral siswa menagalami sedikit kenaikan (lihat tabel 1). Karena analisa statistik yang dipakai adalah analisis deskriptif, yaitu hanya dengan pengelompokan data hasil uji maka signifikansi peningkatannya tidak dapat diketahui dengan jelas.

Tabel 1. Penalaran moral siswa di awal dan akhir program

\begin{tabular}{|c|c|c|}
\hline $\begin{array}{c}\text { Tahap } \\
\text { Penalaran } \\
\text { Moral }\end{array}$ & $\begin{array}{c}\text { Awal } \\
\text { program } \\
(\boldsymbol{\%})\end{array}$ & $\begin{array}{c}\text { Akhir } \\
\text { Program } \\
(\mathbf{\%})\end{array}$ \\
\hline Tahap 1 & 5 & 0,5 \\
\hline Tahap 2 & 77,5 & 22,3 \\
\hline Tahap 3 & 15 & 43,1 \\
\hline Tahap 4 & 2,5 & 31,2 \\
\hline Tahap 5 & & 2,9 \\
\hline
\end{tabular}

Pada tabel 1 dapat sekilas kita ketahui bahwa jumlah prosentase siswa dengan penalaran moral tahap 1 dan 2 mengalami penurunan, sedangkan pada tahap 3 dan 4 mengalami kenaikan, bahkan juga muncul beberapa siswa dengan penalaran moral tahap 5. hal ini menunjukkan bahwa telah terjadi perkembangan penalaran moral, dimana terutama para siswa yang sebelumnya berada di penalaran moral tahap 1 dan 2, menjadi golongan penalaran moral tahap yang lebih tinggi.

Siswa yang memutuskan untuk merespon suatu kejadian yang menurutnya memiliki dampak moral, terlebih dahulu harus memiliki suatu kemampuan untuk menginterpretasikan dan suatu dorongan akan keberadaan nilai moral tersebut. Dalam bahasa yang sederhana, orang itu harus memiliki kepekaan terhadap dampak moral pada semua fenomena di sekitarnya. Tingkat kesensitifan tiap siswa berbeda-beda, sebagai contoh terdapat orang yang memiliki sensitivitas yang tinggi sehingga dalam semua peristiwa yang dialaminya dia dapat merasakan adanya makna dan nilai moral tertentu. Sebaliknya pada orang yang sensitivitasnya rendah sulit untuk mengalami hal tersebut, pada contoh kecil dia mungkin baru tergerak hatinya ketika mengalami peristiwa yang benar-benar hebat seperti melihat pembunuhan yang sadis. Dalam hal ini penelitian implementasi model tematik untuk mengajarkan mata pelajaran Biologi ternyata dapat merubah moral reasoning siswa terhadap nilai moral yang terkandung dalam materi pelajaran biologi.

Berdasarkan proses internalisasi moral, menurut Rest (1995) kesensitifan seseorang akan nilai-nilai moral terhadap berbagai fenomena di sekelilingnya sebenarnya masih merupakan tahap awal bagi penanaman moral dalam diri seseorang. Untuk proses awal dalam internalisasi moral, penelitian ini menunjukkan bahwa perangkat pembelajaran Biologi berorientasi Model 
Pembelajaran Pemaknaan dapat mengajarkan sensitivitas moral kepada siswa.

Menurut penelitian Bandura dan koleganya mulai dari tahun 1962 hingga 1972 (dalam Kurtines dan Gewirtz, 1995) model-model seperti orang tua, guru, teman yang mempraktekkan perilaku moral secara konsisten akan memberikan pengaruh besar terhadap perkembangan moral anak. Dengan demikian "mengajari" moral pada anak-anak memiliki dua dimensi pembelajaran yaitu melalui verbal dan juga melalui perilaku yang dicontohkan oleh para pengajar itu sendiri. Ketika guru mengajarkan adanya nilai-nilai moral melalui pelajaran biologi, pada dasarnya terjadi pembelajaran moral secara verbal dan perilaku berupa kepekaan moral, sehingga akan mendorong munculnya sensitivitas moral dalam diri siswa.

Kepekaan moral merupakan awal yang penting bagi perilaku sosial yang ada pada seseorang. Seperti halnya pada setiap aspek psikologis yang lain, moral reasoning pada diri seseorang juga sangat dipengaruhi oleh lingkungan. Moral reasoning dapat mengalami perubahan secara natural sesuai dengan perkembangan dan kondisi lingkungan yang setiap hari dihadapi oleh seseorang, namun juga bisa mengalami perubahan secara sengaja melalui proses seperti pendidikan. Jenis yang kedua ini oleh Blazi (1995) disebut dengan cultivated moral sensitivity.

Pendidikan sosial memiliki dimensi yang sangat kompleks. Pendidikan menyangkut internalisasi nilai pada diri siswa tidak hanya menyangkut teori, melainkan juga emosi, pengalaman sehari-hari, teladan dan juga pendampingan. Kompleksitas pendidikan sosial dan moral juga ada dalam segi waktu, dimana terdapat hasil internalisasi yang dapat dianalisis dalam waktu yang pendek, namun ada juga yang hanya dapat teramati hasilnya setelah waktu yang sangat lama. Oleh karena itulah diperlukan pendekatan yang inovatif untuk melakukan pendidikan moral (Reiman \& Dotger, 2008). Kedua peneliti ini mengungkapkan bahwa pendekatan pendidikan nilai sosial yang lebih diarahkan pada difusi nilai sosial ke dalam berbagai mata pelajaran memiliki dampak yang lebih baik dari pada hanya melalui satu jenis mata pelajaran khusus untuk pendidikan sosial saja.

Dampak peningkatan moral reasoning tidak hanya terbatas pada aspek afektif dalam diri manusia, namun juga pada aspek kognitif, terutama pada ranah kognitif tingkat tinggi. Hal ini telah sejak lama diungkapkan oleh penelitian yang dilakukan oleh Kholberg (dalam Helen Bee, 1997) bahwa peningkatan aspek moral dalam diri seseorang secara positif sangat didukung oleh perkembangan daya analisis dan sintesis dalam berpikir abstrak.

\subsection{Faktor-faktor yang Berpengaruh pada Pembelajaran}

Faktor-faktor yang memepengaruhi implementasi model tematik ini disimpulkan dari observasi yang telah dilakukan peneliti. Faktor-faktor yang berpengaruh itu antara lain:

1. Tingkat pemahaman siswa terhadap materi

Adanya kelas unggulan yang harus diakui memiliki kemampuan akademik yang lebih tinggi diantara kelas-kelas yang lain mempengaruhi keberhasilan pelaksanaan program ini di dua kelas unggulan (IPA 1 dan IPA 2). Penyesuaian materi dan metode penyampaian kemungkinan dapat membantu mengatasi permasalahn yang disebabkan faktor ini di kelas-kelas non unggulan.

2. Media Pembelajaran.

Media paling mendesak untuk dipenuhi sebenarnya adalah buku pegangan yang dapat dipelajari oleh siswa secara mandiri di luar kelas. Mudahmudahan permasalahn ini dapat diatasi pada pelaksanaan program di tahun-tahun 
mendatang. Media lain seperti video, LCD, computer juga diharapkan membentu pelaksanaan pembelajaran di masa yang akan datang.

3. Jumlah jam Pelajaran.

Satu jam dalam tiap minggu membuat metode diskusi yang sebenarnya menjadi model pembelajaran utama dalam program ini menjadi kurang optimal. Jika memang penambahan jam pelajaran menjadi 2 jam memungkinkan, maka hal tersebut dapat membantu pencapaian tujuan pembelajaran dengan lebih baik.

\section{KESIMPULAN}

Berdasarkan evaluasi pelaksanaan program Sains Integrasi selama tahun kedua di SMAN 3 Pamekasan, tahun ajaran 2007-2008, didapatkan beberapa kesimpulan sebagai berikut: 1) adanya variasi respon siswa terhadap proses pembelajaran yang dijalankan; 2) adanya peningkatan secara umum penalaran moral siswa, walaupun tingkat signifikansinya belum dapat diketahui dengan jelas; dan 3) faktor yang berpengaruh terhadap pelaksanaan program adalah Tingkat pemahaman siswa terhadap materi, media pembelajaran (terutama buku pegangan), dan jumlah jam pelajaran.

\section{DAFTAR PUSTAKA}

Arikunto, Suharsimi. dan Safruddin, Cepi. 2004. Evaluasi Program Pendidikan, Pedoman Teoritis Praktis bagi Praktisi Pendidikan. Penerbit Bumi Aksara. Jakarta

Habibi. 2007. Bahan Ajar Dialektika Pendidikan. STKIP. Sumenep

Higgins, Ann. 1995. Educating for Justice and Community; Lawrence Kholberg's Vision of Moral Education. dalam Kurtines, W.M. \& Gewirtz, J.L. Moral Development, an Introduction. Needham Heights: A Simons and Schuster Company
Homby, A.S., 1995. Oxford Advanced Learner's Dictionary of Current English. Crowther, Jonathan (Ed.). Fifth Edition. Oxford University Press. United Kingdom

Masitah dan Nur, Mohammad. 2004. Teori Perkembangan Sosial dan Perkembangan Moral. Surabaya: Universitas Negeri Surabaya - Pusat Sains dan Matematika Sekolah

Moleong, Lexy J. 2002. Metodologi Penelitian Kualitatif, Edisi Revisi. PT Remaja Rosdakarya Offset. Bandung

Prabowo. 2000. Pembelajaran Fisika dengan Pendekatan Terpadu dalam Menghadapi Perkembangan IPTEK Milenium III. Makalah disampaikan pada Seminar dan Lokakarya Jurusan Fisika FMIPA UNESA bekerja sama dengan Himpunan Fisika Indonesia (HFI) dengan Tema Optimalisasi Peranan Fisika Menghadapi Perkembangan IPTEK Milenium III pada tanggal 10 Februari 2000: Unesa 2000

Prasetya. 2002. Filsafat Pendidikan. Penerbit Pustaka Setia. Bandung.

Subandijah. 1996. Pengembangan dan Inovasi Kurikulum. PT RajaGrafindo Persada. Jakarta

Sukmadinata, Nana Syaodih. 2004. Landasan Psikologi Proses Pendidikan. PT Remaja Rosdakarya. Bandung

Wayan Koyan, I. 2000. Pendidikan Moral Pendekatan Lintas Budaya. Dierektorat Jenderal Pendidikan Tinggi - Departemen Pendidikan nasional: Proyek Pengembangan Guru Sekolah Menengah IBRD Loan No. 397. 